\title{
Current Issues in Histology, Biology and Prognosis of Hodgkin Lymphoma
}

\author{
Goran Marjanović ${ }^{1,2}$, Olivera Simonović ${ }^{2}$ \\ ${ }^{1}$ University of Niš, Faculty of Medicine, Niš, Serbia \\ ${ }^{2}$ Clinic of Hematology and Clinical Immunology, Clinical Center Niš, Niš, Serbia
}

\section{SUMMARY}

High risk Hodgkin lymphoma patients may occasionally have borderline characteristics similar to gray zone lymphomas and T-cell/histiocyte rich B cell lymphomas. These entities require different and more aggressive treatment modalities. Aggressive behavior is often associated with disturbances caused by Epstein Barr virus, or immune evasion caused by overexpression of check point inhibitors PDL-1 and PDL-2 coupled with the lack of expression of Class I and II MHC molecules. Galectin-1, TARC, sCD163 and other surrogate markers of immunosuppression in Hodgkin lymphoma may be useful for the assessment of treatment response. The improvements in lymphoma management diminished the importance of prognostic factors unified in the International Prognostic Scoring system, reducing them from 7 to 3 factors that remained relevant. Interim PET analysis is the only method able to identify resistant patients while chemotherapy is ongoing, thus enabling adjustment of treatment according to the treatment response. Efforts for stratification of patients according to disease histology, biology, microenvironment, clinical scoring systems and PET scan are ongoing. Current breakthroughs have set strong background for novel therapies with monoclonal antibodies and check point inhibitors that will result in improvement of management of high risk patients.

Key words: Hodgkin Lymphoma, prognosis, interim PET, check point inhibition, microenvironment 


\section{INTRODUCTION}

Management of patients with Hodgkin lymphoma has reached the point where the majority of patients are cured, regardless of disease presentation. Disease spectrum varies from low-risk highly curable disease to high-risk relapsing and refractory cases. The former group is often over-treated with unnecessary toxicity, while the letter requires aggressive approach or novel therapies with monoclonal antibodies and check point inhibitors. This has created a need for better balance in treatment according to stratification into the risk groups. The age, stage of the disease, and similar pretreatment parameters are used for this prognostication, but even then, accurate stratification was not always possible and many dilemmas remained unsolved.

Recent years have witnessed breakthroughs in understanding of genetics, biology of Hodgkin lymphoma, and biomarkers with improved prognostic power providing the strong rationale for the implementation of novel therapies. In this review, we will discuss the most important novelties concerning diagnostic dilemmas about resistant entities borderline to Hodgkin lymphoma. The review will continue with prognostic factors detectable before treatment, such as prognostic scoring systems, genetic lesions in Hodgkin lymphoma, and interactions of tumor cells with microenvironment. The final section of this review will end up with treatment response estimation and response-guided treatment, based on novel imaging techniques.

\section{Origin of HRS and LH cells - implications on pathology}

Hodgkin lymphoma is a disease of malignant B lymphocytes with heterogeneous biology, variable histology and clinical characteristics at presentation. These differences led to further division into a group of entities named as classic Hodgkin lymphoma (cHL) and a nodular lymphocyte predominant Hodgkin lymphoma (NLPHL) $(1,2)$. In cHL group, the tumor cells are designated Hodgkin Reed Sternberg cells (HRS), while in NLPHL, they have been named lymphocytic and histiocytic cells (LH).

Both HRS and LH cells derive from germinal centre B cells $(3,4)$. Genetic analysis revealed that both cell types have been activated on their way through the germinal center. A hallmark of this journey is the process of somatic hypermutation with generation of high affinity immunoglobulins and expression of specific B-cell immunophenotype. Therefore, the LH cells on their surface express Bcl-6, HGAL and other molecules, carry somatically mutated $\operatorname{IgV}$ gene segments and grow in a follicular pattern with close interaction with the cells from the microenvironment (4). Apart from the typical follicular growth pattern, two main variations with diffuse growth were described in NLPHD the first, B cellrich nodular serpiginous, and the second, $\mathrm{T}$ cell-rich/ nodular diffuse (5). Diffuse T-cell subtype of NLPHL is difficult to distinguish from $\mathrm{T}$ histiocyte rich large Bcell lymphoma (THRLBCL) (1) Besides an overlap in immunophenotype, both entities have clonally rearranged mutated IGH genes, and have no consistent differentially expressed genes $(6,7)$. The main difference, according to the gene expression profile analysis, is in their microenvironments (7). Accumulating data led to the argument that both entities represent a spectrum of the same disease but the hypothesis that THRLBCL is as a consequence of NLPHD progression could not be proved (7).

Another dilemma concerns the overlap between nodular sclerosis classic Hodgkin lymphoma (NS-cHL), mediastinal gray zone lymphoma (MGZL) and primary mediastinal B-Cell lymphoma (PMBCL) (1). The histology and immunophenotype are frequently asynchronous in PMBCL and MGZL with abundant macrophages and dendritic cells mixed with tumor cells resembling HRS (1). The situation becomes complicated when composite areas resembling two or more the abovementioned entities are all placed in a one case. According to the immunophenotype, mediastinal GZL subtype is considered to be transitioning between PMBCL and NScHL (8). In cHL, HRS on its way through the germinal centre accumulates disadvantageous mutations of heavy and light Ig chain genes, while further transforming events rescue HRS cell from apoptosis. This results in failure to express the functional B-cell receptor $(3,6)$. The lack of expression of B-cell specific antigens occurs probably later in postgerminative center phase (6). These events, all together, create the genetic signature with downregulation of complete B-cell gene program in cHL tumor cells, while this program remains active in GZL. Epigenetic analysis of 30 cases of cHL, PMBL and mediastinal GZL has shown a close relationship but unique signatures (9).

For instance, hypometilation of HOX5 gene was most prominent in CHL, while EPHA7 or DAPK1 in mediastinal GZL and PMBCL, respectively (10). Therefore, reliable distinguishing between over-lapping cases could be achieved with gene expression analysis and epigenetic studies. Further analysis with a larger number of patients is a high priority as well as creating the individually tailored treatment approach (8). 


\section{Microenvironment, immune escape and prognosis}

One of the main characteristics of Hodgkin lymphomas is the low fraction of tumor cells within the total tumor mass (11). HRS and LH cells produce and release the vast array of cytokines that cultivate their environment (12). A myriad of alternatively activated macrophages, $\mathrm{T}$ regulatory cells and follicular dendritic cells in the close proximity to LH and HRS create immunopriviledged environment that is ideal for tumor cell growth and its protection from immune attack $(4,12$, 13). Each of these cell components contribute actively to the progression of the disease.

Macrophages, when found in the increased number, are associated with worse prognosis (14). Their number is increasing with the disease progression, thus correlating with the stage of the disease. Tumor tissue contains various subtypes of these cells like alternatively activated macrophages (M2 cells), myeloid derived suppressor cells and a small number of

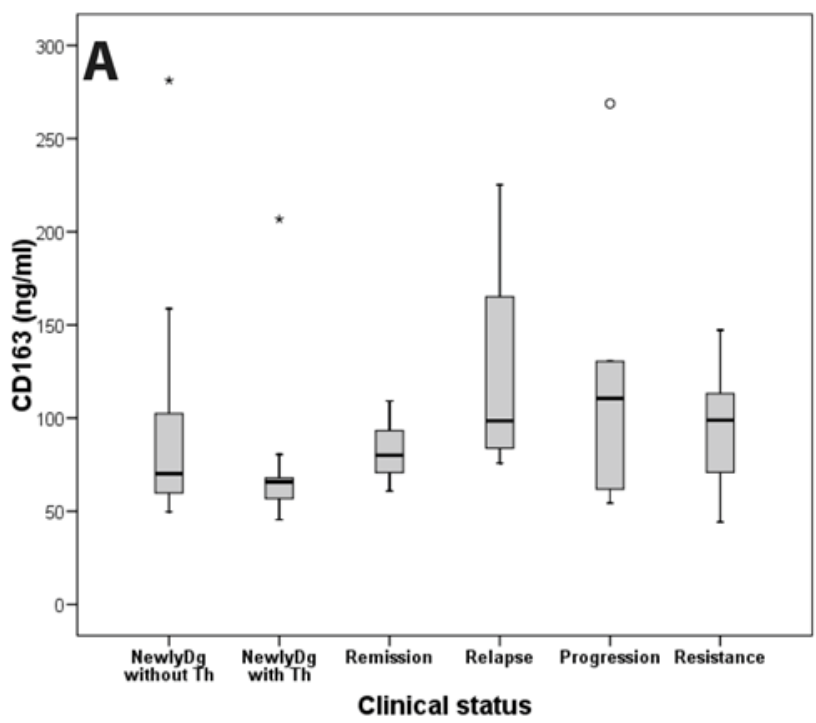

classically activated macrophages; however, this polarization is not as strict in patients as it was observed in vitro (14). The anti-inflammatory function of M2 macrophages is reflected in the secretion of immunosuppressive cytokines (transforming growth factor- $\beta$ ), TGF$\beta 1$, and IL-10, which further induce Th2 differentiation, favoring the development of T-regulatory (Treg) lymphocytes. Taken together, these events promote the growth of tumor by the inhibition of anti-tumor immune response (13). Recently, sCD163 has been used as the surrogate serum marker that reflects the presence of alternatively activated macrophages (M2) in patients with cHL (13). The reliability of sCD163 as a marker of immunosuppression in cHL is a matter of debate, since macrophages taken from biopsy tissue do not show strong dichotomy as seen in animal models, and are more likely the hybrid cells (13). Nevertheless, sCD163 has shown the ability to characterize disease status and the response to therapy (15),(Figure 1).

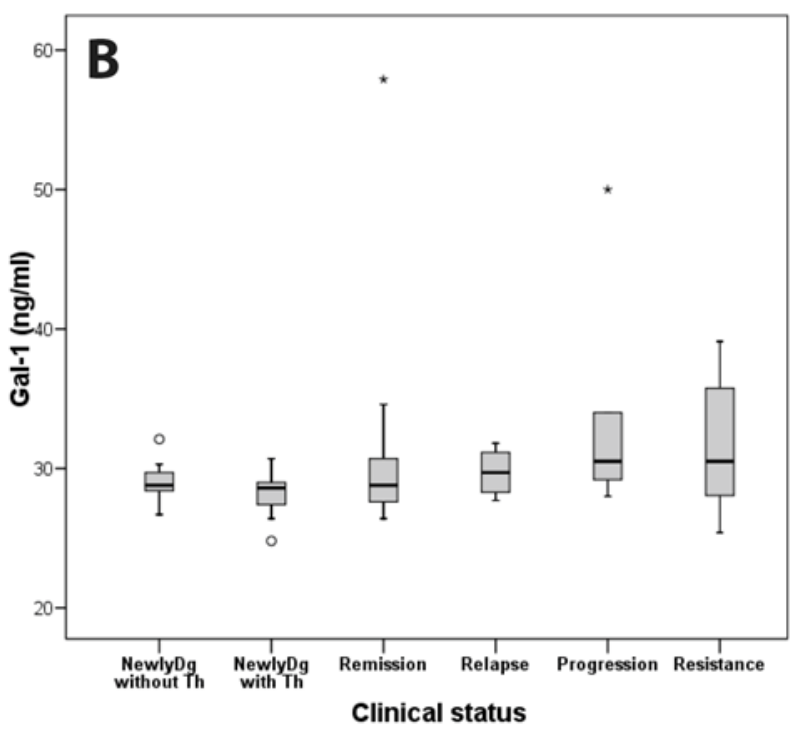

Figure 1.

A: Higher values of serum CD163 in relapsing, chemoresistant or progressive cHL patients.

B: Higher values of galectin-1 in relapsing, chemoresistant or progressive cHL patients

(Simonović et al. (16))

$\mathrm{T}$ cells population also play an important role in Hodgkin lymphomas. The decision which $\mathrm{T}$ cell subset will predominate in the microenvironment is strongly dictated by Reed Sternberg cells. It was found that HRS cells selectively recruit Th2 and Tregs by producing chemoattractants including TARC/CCL17, CCL5, CCL22, IL5, IL-4, IL-10 $(12,16)$. The abovementioned cytokines were found to be associated with inferior response to therapy $(2,16,17)$. Another cause of ineffective T cell response is in functional reprogramming of T cells. HRS cells in CHL express important check point inhibitors PD-L1 and PD-L2, resulting with exhaustion of T cell response. This event induces consecutive expression of PD-1 and PD-2 receptors on the surface of the counterpart $\mathrm{T}$ cells, with further impairment of immune response and adverse prognosis $(12,18)$. Further functional reprogramming of $\mathrm{T}$ cells is facilitated by secretion of galectin-1 from HRS. Galectin-1 belongs to a group 
of proteins with an affinity for binding carbohydrates. Immunosuppressive function of galectin- 1 is reflected in the inhibition of secretion of IL-2, interferon- $\gamma$ and tumor necrosis factor $\alpha$, and initiation of IL-10 production. Furthermore, it selectively kills Th17 cells, influences the polarization of Th1 response in the direction of Th2 response, inducing Th1 cell apoptosis $(19,20)$. Therefore, galectin- 1 is considered as an indicator of immunosuppression caused by the malignant HRS cells, and the indicator of absence of Th1 anti-tumor immunoresponse (20). The levels of this serum biomarker seem to correlate with tumor burden, disease stage, prognosis and response to therapy, $(15,16,21,22)$. The list of serum biomarkers is not final and besides IL-10, TARC, galectin-1, sCD163 includes sCD30 and many others but their importance and reliability remain to be confirmed in further studies.

Finally, immune escape of Reed Sternberg cells may be due to the lack of expression of $\beta 2$ micro globulin/ MHC I and MHC II molecules on the HRS surface. Their role is crucial for the recognition of tumor cells by CD4+ and CD8+ T cells. The lack of $\beta 2$ micro-globulin and MHC I is a very common event with the incidence of $64-79 \%$ in various patient cohorts $(23,24)$. Most commonly, the main driving force of immunosuppression is the loss of MHC I molecule expression caring adverse prognosis equally in isolated and concomitant defects (24).

The loss of MHC II surface expression is also a common event, where in 292 baseline Hodgkin lymphoma biopsies it was $41.4 \%$, while in the cohort of 108 cases it reached $67 \%$ and was associated with adverse prognosis $(24,25)$.

\section{Genetic lesions in Hodgkin lymphoma}

HRS and LH cells have a considerable genetic instability. Among the most common extrinsic causes of instability is the latent infection with Epstein Barr virus (EBV). In $40 \%$ of cases of classic Hodgkin lymphoma subtype, EBV genes were constitutively expressed (27). In addition to EBV nuclear antigen, two membrane EBV proteins, latent membrane protein 1 and 2 (LMP-1 and LMP-2) could be also found on the surface of HRS (27). These molecules may mediate stimulatory survival signals, with LMP-1 mimicking an active CD40 receptor, while LMP-2 provides signals equivalent to B-cell receptor $(27,28)$. Further interactions between those molecules and microenvironment lead to deregulated active tion of signaling pathways and further genetic lesions. In that way, a NanoString digital expression profiling revealed a 23-gene signature which was able to reco- gnize high-risk subset of advanced stage HL patients (29). In HRS, deregulation of transcription factors might be recurrent and independent of EBV infection. Most frequent deregulations are in $\mathrm{NF \kappa B}$ signaling pathway with deletions of NFKBiA, NFKBiE and TNFAIP3 genes and Rel MAP3K14 gains $(26,30)$. Another important disruption is seen in JAK/STAT signaling pathway (26, 30). The deletion of the main inhibitor SOCS1 within this pathway could be found in $40 \%$ of HL cases (30). This lesion is highly disruptive in $90 \%$ of STAT6 mutated cHL cases (30). Other important gain is in JAK2 kinase. Recent analysis of HRS cell cultures, as well as analysis of microdissected paraffin embedded tumor cells, reveled gains of 9p24.1 chromosome region to be a typical and recurrent genetic lesion in Hodgkin lymphoma (31). The 9p24.1 lesion rearrange genes for programmed death ligands 1 and 2 (PD-L1 and PDL2), leading to their copy number alteration, most frequently due to gene amplification (32). Amplification process leads to higher expression of PD-L1 and PD-L2 receptors on the tumor cell surface, contributing the inhibition of anti-tumor immunity through immune escape mechanism (32). Recent observations have created a strong rationale for targeting PD-L1 mediated tumor escape with humanized antibodies such as Pembrolizumab with encouraging results.

\section{Clinical prognostic scoring systems}

The stratification of newly diagnosed patients with high risk for many years was based on the advanced clinical stage and signs of activity of the lymphoma. Integration of these parameters has lead to prognostic score introduced by German Hodgkin Study Group (GHSG) or Hasenclever scoring system (International Prognostic Score - IPS) (34). This model was retrospectively developed in 1998, based on the results of therapy with protocols used before 1992 that are inferior to regimens currently used for standard care. The cohort of patients had insufficient number of patients with the advanced age and the high risk group was very small. Scoring system used the seven clinical parameters, namely: age $<45$ years, male sex, stage IV of the disease, hemoglobin $<105 \mathrm{~g} / \mathrm{L}$, white blood count $(\mathrm{WBC})>15 \times 109 / \mathrm{L}$, lymphocyte count $<0.6 \times$ $109 / \mathrm{L}$ or $<8 \%$ of total WBC and albumin $<40 \mathrm{~g} / \mathrm{L}$.

A retrospective analysis from British Columbia Cancer Agency in patients treated between 1980 and 2010 with ABVD or equivalent antracyclin containing protocol reported a diminished prognostic range, remaining prognostic for advanced stage HL (34). Therapeutic advances due to increased diagnostic accuracy, imp- 
roved supportive care with growth factors and improved imaging modalities with positron emission tomography -PET/CT along with the use of stem cell transplant at relapse led to the loss of predictive power of certain originally described risk factors. In attempt to refine risk assessment, Diefenbach et al. created a score with three factors whose power remained predictive for freedom from progression (FFP) and overall survival (OS). The so called IPS-3 was constructed using age > 45 years, stage IV and hemoglobin $<105 \mathrm{~g} / \mathrm{L}$ which provided 4 distinct risk groups (34). In this study, clinical data from study E2496 with 845 patients were used to compare IPS-3 with IRS-7 $(35,36)$. The IPS-3 outperformed the IPS-7 on risk prediction for both FFP and OS.

A potential concern of the abovementioned results lie in the applicability of IPS-3 in patients treated with protocols such are escalated BEACOPP or novel therapies, since the patients in E2496 study were treated with either ABVD or Standford V regimens. This study also had a small number of patients with maximum risk factors present and limited number of patients reclassified from IPS-7 high risk to IPS-3 intermediate risk, without difference in OS $(35,36)$. Another pitfall of IPS system is in the lack of successful integration with markers of tumor biology and microenvironment.

\section{Interim PET evaluation}

The majority of factors discussed above determine the disease status before the start of the treatment, while few of them provide sufficient information during the course of treatment. Apart from previously described variable serological markers, functional imaging with 18-Fluorodexyglucose-(FDG) positron emission tomography PET/CT has emerged as reliable and recognizable mean for the assessment of stage of the disease, early treatment response and the end of therapy $(37,38)$. Standardization of the FDG uptake has led to the development of a five-point scale known as "Douville criteria" (39). It includes the following elements: (1) no uptake, (2) uptake higher than or equal to mediastinal blood pool, (3) uptake higher than mediastinal blood pool but lower than or equal to the liver, (4) uptake higher than the liver, (5) uptake markedly higher than the liver (40). The score from 1 to 2 is considered normal or equal to complete metabolic response in limited stages, while for the advanced Hodgkin lymphoma the cut-off score is 1-3 $(40,41)$.

The use of interim PET in limited stage low risk Hodgkin lymphoma has set the ground for reducing chemotherapy and radiotherapy while maintaining the cure rate. In GHSG HD10 study, initial treatment with 2 cycles of ABVD chemotherapy after interim PET scan in negative cases continued with reduced dose of radiotherapy with only $20 \mathrm{~Gy}$. Within this subgroup, the excellent results of $95 \%$ OS and $86 \%$ PFS at 8 years were recorded (42). The NCIC HD6 study in the same low risk group has proven that radiotherapy can be omitted in PET negative patients. Patients in this subgroup, after 2 cycles of ABVD, received 4 additional cycles of $\mathrm{ABVD}$ without radio therapy. The 12 -year OS - $92 \%$ and PFS - $86 \%$ was superior in this subgroup in comparison to patients treated with additional radiotherapy due reduced incidence of late toxic events (43). Conversely, in PET positive early favorable patients in GHSG HD10 study, after 2 cycles of ABVD chemotherapy, the treatment could be intensified by adding 2 cycles of escalated BEACOPP with favorable response in slowly reactive and potentially resistant cases (42).

According to the results of at GSHG HD14 study, the treatment of early unfavorable Hodgkin lymphoma after 2 initial cycles of escalated BEACOPP in interim PET negative cases could be reduced with additional 2 ABVD regimens, but the local radiotherapy should not be omitted (45). The necessity of keeping radiotherapy in interim PET negative early unfavorable lymphoma cases had been additionally proven in EORTC/LYSA/FIL H10 trial. In the subgroup deprived of radiotherapy, PFS after 5 years was worse due to the loss of local disease control $(45,46)$.

Another reduction of therapy with omitting the Bleomcyin from ABVD in advanced Hodgkin lymphoma interim PET negative patients was safe and without significant impact on the OS (47). The 3-year OS after 6 cycles of AVD in PET negative subgroup was $97.6 \%$ that was comparable with $97.2 \%$ OS after 6 ABVD cycles in the same PET negative group (47). These reductions were not advisable in PET negative subgroups in early forms of Hodgkin lymphomas where the number of ABVD and AVD cycles is considerably smaller $(48,49)$. Interim PET driven therapy of advanced Hodgkin lymphoma in the subgroup of positive patients in the RATLE study after 2 ABVD courses also found benefit when turned to 3 escalated BEACOPP-s or 4 standard BEACOPP - 14 cycles. In spite of PFS and OS improvement in this high risk advanced patient subgroup, overall results are unsatisfactory with the need for applying different treatment approaches (47).

Taken together, new genetic, histological and serological markers have shown the ability to identify high risk patients. Integration of these novelties into 
revised scoring systems combined with risk-adapted therapy is the task for future clinical studies. Their results, combined with therapy with monoclonal anti- bodies and check point inhibitors will result in improvements in the management of these selected high risk groups of patients.

\section{References}

1. Jaffe ES, Harris NL, Stein H, et al. World Health Organization Classification of Tumours: Pathology and Genetics of Tumours of the Haematopoietic and Lymphoid Tissues, in: IARC WHO Classification of Tumours. IARC Press, Lyon, France; 2001.

2. Swerdlow SH, Campo E, Pileri SA et al. The 2016 revision of the World Health Organization classification of lymphoid neoplasms. Blood 2016; 127: 2375-90.

https://doi.org/10.1182/blood-2016-01-643569

3. Schmitz R, Stanelle J, Hansmann ML, et al. Pathogenesis of classical and lymphocyte-predominant Hodgkin lymphoma. Annu Rev Pathol. 2009; 4: 15174

https://doi.org/10.1146/annurev.pathol.4.110807.09 $\underline{2209}$

4. Kuppers R. New insights in the biology of Hodgkin lymphoma. Hematology Am Soc Hematol Educ Program 2012; 2012: 328-34.

5. Fan Z, Natkunam Y, Bair E, et al. Characteri zation of variant patterns of nodular lymphocyte predominant hodgkin lymphoma with immunohistologic and clinical correlation. Am J Surg Pathol 2003; 27: 1346-56.

https://doi.org/10.1097/00000478-200310000-00007
6. Boudova L, Torlakovic E, Delabie J et al. Nodular lymphocyte-predominant Hodgkin lymphoma with nodules resembling $\mathrm{T}$-cell/histiocyte-rich B-cell lymphoma: differential diagnosis between nodular lymphocyte-predominant Hodgkin lymphoma and T-cell/histiocyte-rich B-cell lymphoma. Blood 2003; 102: 3753-8.

https://doi.org/10.1182/blood-2003-02-0626

7. Clemente CD. Gray's Anatomy 30th American Ed. Philadelphia, The veins, Lea and Febiger, 1985; p. 820-1. Hartmann S, Doring C, Jakobus C et al. Nodular lymphocyte predominant hodgkin lymphoma and $\mathrm{T}$ cell/histiocyte rich large $\mathrm{B}$ cell lymphomaendpoints of a spectrum of one disease? PLoS One 2013; 8: e78812.

https://doi.org/10.1371/journal.pone.0078812

8. Dunleavy K, Wilson WH. Primary mediastinal B-cell lymphoma and mediastinal gray zone lymphoma: do they require a unique therapeutic approach? Blood 2015; 125: 33-9. https://doi.org/10.1182/blood-2014-05-575092

9. Yuan J, Wright G, Rosenwald A et al. Identification of Primary Mediastinal Large B-cell Lymphoma at Nonmediastinal Sites by Gene Expression Profiling. Am J Surg Pathol 2015; 39: 1322-30. https://doi.org/10.1097/PAS.0000000000000473 
10. Eberle FC, Rodriguez-Canales J, Wei L et al. Methylation profiling of mediastinal gray zone lymphoma reveals a distinctive signature with elements shared by classical Hodgkin's lymphoma and primary mediastinal large B-cell lymphoma. Haematologica 2011 ; 96: 558-66.

https://doi.org/10.3324/haematol.2010.033167

11. Pileri SA, Ascani S, Leoncini L et al. Hodgkin's lymphoma: the pathologist's viewpoint. J Clin Pathol 2002; 55: 162-76.

https://doi.org/10.1136/jcp.55.3.162

12. Vardhana $S$, Younes A. The immune microenvironment in Hodgkin lymphoma: T cells, B cells, and immune checkpoints. Haematologica 2016; 101: 794-802.

https://doi.org/10.3324/haematol.2015.132761

13. Gascoyned RD, Scott DW, Steidl C. Molecular Pathology of Hodgkin's lymphoma: prognostic implicationes: Hematology Education: the education program for the annual Congress of the European Hematology Association 2012; 6: 16574.

14. Steidl C, Lee T, Shah SP et al. Tumor-associated macrophages and survival in classic Hodgkin's lymphoma. N Engl J Med 2010; 362: 875-85 https://doi.org/10.1056/NEJMoa0905680

15. Plattel WJ, Alsada ZN, van Imhoff GW et al. Biomarkers for evaluation of treatment response in classical Hodgkin lymphoma: comparison of sGalectin-1, sCD163 and sCD30 with TARC. Br J Haematol 2016; 175: 868-75.

https://doi.org/10.1111/bjh.14317

16. Simonović $\mathrm{O}$, Todorović $\mathrm{M}$, Mihaljević $\mathrm{B}$ et al. Serum biomarkers and clinical characteristics of patients with Hodgkin lymphoma. Vojno Sanit Pregl 2017; Online first February. http://doi.org/10.2298/VSP160705018S

17. Hnatkova M, Mocikova $H$, Trneny $M$, et al. The biological environment of Hodgkin's lymphoma and the role of the chemokine CCL17/TARC. Prague Med Rep 2009; 110: 35-41.

18. Sauer M, Plutschow A, Jachimowicz RD et al. Baseline serum TARC levels predict therapy outcome in patients with Hodgkin lymphoma.

Am J Hematol 2013; 88: 113-5.

https://doi.org/10.1002/ajh.23361

19. Chemnitz JM, Eggle D, Driesen J et al. RNA fingerprints provide direct evidence for the inhi bitory role of TGFbeta and PD-1 on CD4+ T cells in Hodgkin lymphoma. Blood 2007; 110: 3226-33. https://doi.org/10.1182/blood-2006-12-064360

20. Tsai CM, Chiu YK, Hsu TL et al. Galectin-1 promotes immunoglobulin production during plasma cell differentiation. J Immunol 2008; 181: 4570-9.

https://doi.org/10.4049/jimmunol.181.7.4570

21. Ouyang J, Plutschow A, Pogge von Strandmann E et al. Galectin-1 serum levels reflect tumor burden and adverse clinical features in classical Hodgkin lymphoma. Blood 2013; 121: 3431-3.

https://doi.org/10.1182/blood-2012-12-474569

22. Kamper $\mathrm{P}$, Ludvigsen $\mathrm{M}$, Bendix $\mathrm{K}$ et al. Proteomic analysis identifies galectin-1 as a predi ctive biomarker for relapsed/refractory disease in classical Hodgkin lymphoma. Blood 2011; 117: 6638-49.

https://doi.org/10.1182/blood-2010-12-327346

23. Plattel WJ, Van den Berg A, Alsada Z et al. Comparison of serial plasma galectin-1 sCD163 and sCD30 with plasma TARC levels as circula ting biomarkers for response evaluation in classi cal Hodgkin lymphoma. Klin Pediatr 2014; 226: 0 -07 .

https://doi.org/10.1055/s-0034-1371117

24. Reichel J, Chadburn A, Rubinstein PG et al. Flow sorting and exome sequencing reveal the onco genome of primary Hodgkin and Reed-Sternberg cells. Blood 2015; 125: 1061-72.

https:/doi.org/10.1182/blood-2014-11-610436

25. Roemer MG, Advani RH, Redd RA et al. Classical Hodgkin Lymphoma with Reduced beta2M/MHC Class I Expression Is Associated with Inferior Outcome Independent of 9p24.1 Status. Cancer Immunol Res 2016; 4: 910-6. https://doi.org/10.1158/2326-6066.CIR-16-0201

26. Diepstra A, van Imhoff GW, Karim-Kos HE et al. HLA class II expression by Hodgkin Reed- 
Sternberg cells is an independent prognostic factor in classical Hodgkin's lymphoma. J Clin Oncol 2007; 25: 3101-8. https://doi.org/10.1200/JCO.2006.10.0917

27. Kuppers R. Molecular biology of Hodgkin lymphoma. Hematology Am Soc Hematol Educ Program 2009; 2009: 491-6.

https://doi.org/10.1182/asheducation-2009.1.491

28. Kilger E, Kieser A, Baumann $\mathrm{M}$ et al. Epstein-Barr virus-mediated B-cell proliferation is dependent upon latent membrane protein 1 , which simulates an activated CD40 receptor. EMBO J 1998; 17: 1700-9.

https://doi.org/10.1093/emboj/17.6.1700

29. Mancao C, Hammerschmidt W. Epstein-Barr virus latent membrane protein $2 \mathrm{~A}$ is a $\mathrm{B}$-cell receptor mimic and essential for B-cell survival. Blood. 2007;110(10):3715-21.

https://doi.org/10.1182/blood-2007-05-090142

30. Mathas S, Hartmann S, Kuppers R. Hodgkin lymphoma: Pathology and biology. Semin Hematol 2016; 53: 139-47.

https://doi.org/10.1053/j.seminhematol.2016.05.007

31. Scott DW, Chan FC, Hong F et al. Gene expression-based model using formalin-fixed paraffinembedded biopsies predicts overall survival in advanced-stage classical Hodgkin lymphoma. J Clin Oncol 2013; 31: 692-700.

https://doi.org/10.1200//CO.2012.43.4589

32. Roemer MG, Advani RH, Redd RA et al. Classical Hodgkin Lymphoma with Reduced beta2M/MHC Class I Expression Is Associated with Inferior Outcome Independent of 9p24.1 Status. Cancer Immunol Res. 2016; 4: 910-6.

https://doi.org/10.1182/blood-2010-05-282780

33. Green MR, Monti S, Rodig SJ et al. Integrative analysis reveals selective 9p24.1 amplification, increased PD-1 ligand expression, and further induction via JAK2 in nodular sclerosing Hodgkin lymphoma and primary mediastinal large B-cell lymphoma. Blood 2010; 116: 3268-77.

https://doi.org/10.1182/blood-2010-05-282780
34. Hasenclever D, Diehl V. A prognostic score for advanced Hodgkin's disease. International Prognostic Factors Project on Advanced Hodgkin's Disease. N Engl J Med 1998; 339:1506-14. https://doi.org/10.1056/NEJM199811193392104

35. Moccia AA, Donaldson J, Chhanabhai $\mathrm{M}$ et al. International Prognostic Score in advanced-stage Hodgkin's lymphoma: altered utility in the modern era. J Clin Oncol 2012; 30: 3383-8. https://doi.org/10.1200/JCO.2011.41.0910

36. Diefenbach CS, Li H, Hong F et al. Evaluation of the International Prognostic Score (IPS-7) and a Simpler Prognostic Score (IPS-3) for advanced Hodgkin lymphoma in the modern era. Br J Haematol 2015; 171: 530-8.

https://doi.org/10.1111/bjh.13634

37. Gordon LI, Hong F, Fisher RI et al. Randomized phase III trial of ABVD versus Stanford V with or without radiation therapy in locally extensive and advanced-stage Hodgkin lymphoma: an inter group study coordinated by the Eastern Coope rative Oncology Group (E2496). J Clin Oncol 2013; 31: 684-91.

https://doi.org/10.1200//CO.2012.43.4803

38. Juweid ME, Stroobants S, Hoekstra OS et al. Use of positron emission tomography for response assessment of lymphoma: consensus of the Imaging Subcommittee of International Harmonization Project in Lymphoma. J Clin Oncol 2007; 25: 571-8.

https://doi.org/10.1200/JCO.2006.08.2305

39. El-Galaly TC, d'Amore F, Mylam KJ et al. Routine bone marrow biopsy has little or no therapeutic consequence for positron emission tomography computed tomography-staged treatment-naive patients with Hodgkin lymphoma. J Clin Oncol 2012; 30: 4508-14.

https://doi.org/10.1200//CO.2012.42.4036

40. Meignan M, Gallamini A, Haioun C. Report on the First International Workshop on Interim-PETScan in Lymphoma. Leuk Lymphoma 2009; 50: 1257-60.

https://doi.org/10.1080/10428190903040048 
41. Agostinelli C, Gallamini A, Stracqualursi L et al. The combined role of biomarkers and interim PET scan in prediction of treatment outcome in classical Hodgkin's lymphoma: a retrospective, European, multicentre cohort study. Lancet Haematol. 2016; 3: e467-e79.

https://doi.org/10.1016/S2352-

3026\%2816\%2930108-9

42. Biggi A, Gallamini A, Chauvie S, Hutchings M, Kostakoglu L, Gregianin M, et al. International

validation study for interim PET in ABVD-treated, advanced-stage hodgkin lymphoma: interpretation criteria and concordance rate among reviewers. J Nucl Med 2013; 54: 683-90.

https://doi.org/10.2967/jnumed.112.110890

43. Engert A, Plutschow A, Eich HT et al. Reduced treatment intensity in patients with early-stage Hodgkin's lymphoma. N Engl J Med 2010; 363: 640-52.

https://doi.org/10.1056/NEJMoa1000067

44. Meyer RM, Gospodarowicz MK, Connors JM et al. ABVD alone versus radiation-based therapy in limited-stage Hodgkin's lymphoma. N Engl J Med 2012; 366: 399-408.

https://doi.org/10.1056/NEJMoa1111961

45. von Tresckow B, Plutschow A, Fuchs M et al. Dose-intensification in early unfavorable Hodgkin's lymphoma: final analysis of the German Hodgkin Study Group HD14 trial. J Clin Oncol 2012; 30: 907-13.

https://doi.org/10.1200/JCO.2011.38.5807
46. Raemaekers JM, Andre MP, Federico $\mathrm{M}$ et al. Omitting radiotherapy in early positron emission tomography-negative stage I/II Hodgkin lympho ma is associated with an increased risk of early relapse: Clinical results of the preplanned interim analysis of the randomized EORTC/LYSA/FIL H10 trial. J Clin Oncol 2014; 32: 1188-94. https://doi.org/10.1200//CO.2013.51.9298

47. Radford J, Illidge $\mathrm{T}$, Counsell $\mathrm{N}$ et al. Results of a trial of PET-directed therapy for early-stage Hodgkin's lymphoma. N Engl J Med 2015; 372: 1598-607. https://doi.org/10.1056/NEJMoa1408648

48. Johnson P, Federico M, Kirkwood A et al. Adapted Treatment Guided by Interim PET-CT Scan in Advanced Hodgkin's Lymphoma. N Engl J Med 2016; 374: 2419-29. https://doi.org/10.1056/NEJMoa1510093

49. Behringer K, Goergen H, Hitz F et al. Omission of dacarbazine or bleomycin, or both, from the ABVD regimen in treatment of early-stage favour able Hodgkin's lymphoma (GHSG HD13): an open-label, randomised, non-inferiority trial. Lancet. 2015; 385: 1418-27.

https://doi.org/10.1016/S01406736\%2814\%2961469-0

50. Borchmann S, von Tresckow B, Engert A. Current developments in the treatment of early-stage classical Hodgkin lymphoma. Curr Opin Oncol. 2016; 28: 377-83.

https://doi.org/10.1097/CCO.0000000000000314 


\title{
Aktuelne teme $u$ histologiji i biologiji i prognoza Hočkinovog Limfoma
}

\author{
Goran Marjanović ${ }^{1,2}$, Olivera Simonović ${ }^{2}$ \\ ${ }^{1}$ Univerzitet u Nišu, Medicinski fakultet, Niš, Srbija \\ ${ }^{2}$ Klinika za hematologiju i kliničku imunologiju, Klinički centar Niš, Niš, Srbija
}

\section{SAŽETAK}

Oboleli od Hočkinovog limfoma sa visokim rizikom neretko imaju patohistološke karakteristike entiteta sa graničnim osobinama kao što su limfomi sive zone, ili nehočkinski B ćelijski limfom bogat $\mathrm{T}$ ćelijama $\mathrm{i}$ histiocitima. Ovi entiteti zahtevaju agresivniji terapijski pristup. Agresivan tok je često posledica infekcije Epštajn-Barovim virusom ili imunskim poremećajem usled hiperekspresije kontrolnih inhibitornih molekula PDL-1 i PDL-2 udruženim sa odsustvom ekspresije MHC molekula I i II klase. Surogat markeri imunosupresije, kao što su galektin-1, TARC, sCD163 mogu biti korisni za procenu odgovora na terapiju. Napredak u terapiji limfoma je smanjio značaj prognostičkih faktora revidirajući Internacionalni prognostički skoring sistem smanjenjem sa 7 na tri faktora koji su zadržali prediktivnu sposobnost. Istovremena PET analiza tokom terapije je jedina metoda koja može da identifikuje rezistentne bolesnike u toku lečenja, čime je omogućena izmena tretmana u skaldu sa terapijskim odgovorom.

Nastojanja za stratifikovanje bolesnika na osnovu histologije, biologije, sastava mikrookoline, kliničkih skoring sistema i PET sken analize i dalje traju. Savremena dostignuća u ovim oblastima postavila su izvanrednu osnovu za primenu novih terapija monoklonskim antitelima i inhibitorima kontrolnih tačaka imunog odgovora, čime su se stekli uslovi za poboljšanje rezultata lečenja visokorizičnih bolesnika.

Ključne reči: Hočkinov limfom, prognoza, istovremena PET analiza, inhibitori kontrolnih tačaka, mikrookruženje 